\title{
Chronic Chagas' Disease: Targeting the Interleukin-2 Axis and Regulatory T Cells in a Condition for Which There Is No Treatment
}

\author{
Jose Mengel ${ }^{1,2 *}$, Fabiola Cardillo ${ }^{3}$ and Lain Pontes-de-Carvalho ${ }^{3+}$ \\ ${ }^{1}$ Laboratory of Clinical Immunology, Oswaldo Cruz Institute (FIOCRUZ), Rio de Janeiro, Brazil, ${ }^{2}$ Laboratory of Clinical \\ Immunology, Faculty of Medicine of Petrópolis-FASE, Rio de Janeiro, Brazil, ${ }^{3}$ Gonçalo Moniz Research Center, FIOCRUZ, \\ Salvador, Brazil
}

Keywords: interleukin-2, CD25, regulatory T cells, Trypanosoma cruz, Chagas disease, IL-10

\section{OPEN ACCESS}

Edited by:

Heinrich Korner,

Menzies Research Institute Tasmania,

Australia

Reviewed by:

Julia Walochnik,

Medical University of Vienna, Austria

Edgar M. Carvalho,

Universidade Federal da Bahia, Brazil

${ }^{\star}$ Correspondence:

Jose Mengel

jomenge/@terra.com.br

${ }^{\dagger}$ In Memoriam:

Lain Pontes-de-Carvalho

Specialty section:

This article was submitted to

Microbial Immunology,

a section of the journal

Frontiers in Microbiology

Received: 01 January 2016 Accepted: 25 April 2016 Published: 13 May 2016

Citation:

Mengel J, Cardillo F and Pontes-de-Carvalho L (2016) Chronic Chagas' Disease: Targeting the Interleukin-2 Axis and Regulatory T Cells in a Condition for Which There Is No Treatment. Front. Microbiol. 7:675. doi: 10.3389/fmicb.2016.00675

\section{INTRODUCTION}

The intracellular protozoan parasite Trypanosoma cruzi causes Chagas' disease in humans (Mengel and Rossi, 1992; Rassi et al., 2010). According to the latest studies, about 5-8 million people are infected by this parasite around the world, representing a significant global economic burden (Rassi et al., 2010; Lee et al., 2013; Maguire, 2015). The infection may be divided in acute, indeterminate and chronic (Mengel and Rossi, 1992; Andrade et al., 2014). The acute disease, much less frequent nowadays, may be, in most patients, successfully treated with benznidazole, a drug that efficiently kills the parasite (Rassi et al., 2010). On the other hand, the chronic disease is by far the most important condition, concerning the total number of infected people. The chronic disease is characterized by a persistent inflammatory reaction and destruction of host cells, affecting mainly the peripheral autonomous nervous system in the gastrointestinal tract, the heart muscle and intracardiac nerves in $\sim 30-40 \%$ of the infected patients, causing the development of megaesophagus and megacolon, and cardiomegaly associated with progressive and untreatable heart failure, in addition to an increased frequency of sudden death (Andrade et al., 2014). Yet, the majority (about $60-70 \%$ ) of the patients that progress to the chronic phase remain clinically asymptomatic (Umezawa et al., 2001). Contrarily to most predictions, a large, multicentric, placebo-controlled, double-blinded clinical trial has shown that treatment with benznidazole has failed to modify the clinical outcome of chronic Chagas' disease, in spite of promoting a significant parasite load reduction (Morillo et al., 2015). these results argue that the treatment concept fails rather than the anti-parasite effect of the drug itself, suggesting that the presence of the parasite in the chronic infection may not be the only factor responsible for its clinical progression but perhaps a chronic infection that is inappropriately dealt with by the host defenses would be a major question, possibly involving a malfunction of regulatory immune mechanisms and autoimmune phenomena (Mengel and Rossi, 1992; Cardillo et al., 2015). This theoretical framework also accommodates most chronically T. cruzi-infected patients, where this malfunction of regulatory immune mechanisms would not take place, a balanced immune response would be achieved, and pathology would not prevail (Cardillo et al., 2015).

\section{REGULATORY T CELLS IN CHAGAS' DISEASE}

Regulatory $\mathrm{T}$ cells may curb inflammatory responses, allowing a partially effective anti-parasite immune response to remain active. In fact, the role of $\mathrm{CD} 4^{+} \mathrm{CD} 25^{+} \mathrm{Foxp} 3^{+}$Treg cells during the chronic T. cruzi infection has been evaluated in mouse and humans. The most recent studies have 
suggested an important role for this $\mathrm{T}$ cell subpopulation in the chronic disease. For instance, recent findings in humans have shown an increased percentage of Treg cells in chagasic subjects in the indeterminate chronic phase of the infection (free of disease) when compared to patients with heart damage, suggesting an important role for Tregs in Chagas' disease (de Araujo et al., 2011).

In addition, in vivo Treg blockade by using nondepleting monoclonal antibodies to CD25, a marker for these cells, diminished the myocardial inflammation in the chronic infection, a finding that was partially ascribed to consequent increased levels of IL-2 secretion and expansion of CD $4{ }^{+} \mathrm{CD} 25^{+}$ regulatory T cells (Nihei et al., 2014; Bonney and Engman, 2015), providing an indication that the functional activity of Treg cells might be of critical importance during the chronic phase of the infection. It should be noted that not all $\mathrm{CD} 4^{+} \mathrm{CD} 25^{+}$foxp $3^{+}$ $\mathrm{T}$ cells in humans are suppressive and a fraction of them have other effector functions (Miyara et al., 2015). It was recently described that the expression of CD15s (sialyl Lewis $\mathrm{x}$ ) identifies the most suppressive foxp3 high regulatory $\mathrm{CD} 4^{+} \mathrm{CD} 25^{+} \mathrm{T}$ cells (Miyara et al., 2015), discriminating suppressive from effector $\mathrm{CD}^{+} \mathrm{CD}_{2} 5^{+}$foxp $3^{+} \mathrm{T}$ cells in humans. Interestingly, a previously published study has described that the expression of CD15s was decreased in peripheral blood lymphocytes from patients with severe Chagas' disease (Laucella et al., 2001). Therefore, the expression of CD15s in Tregs may be also relevant to predict progression to pathology or treatment efficacy in chagasic patients and further studies concerning this point are warranted.

Administration of nondepleting anti-CD25 mAb increases the production of IL-10 by T cells during the chronic T. cruzi infection in mice (Nihei et al., 2014). It is clear that IL-10 is a pro-survival cytokine during the acute infection, by controlling immune hyperactivation and/or by increase immunity to the parasite (Hunter et al., 1997; Roffe et al., 2012). In Chagas disease, IL-10 seems to be part of a regulated, nonpathogenic immune response in patients without cardiomyopathy (Poveda et al., 2014). These studies suggest that exogenous IL-10 supplementation may be helpful in the control of myocarditis during Chagas' disease. Pegylated IL-10 shows an increased in vivo half-life and helps in the activation of CD8 $\mathrm{T}$ cells. This activity would certainly be important in the control of residual tissue infection ( $\mathrm{Oft}, 2014)$. Additionally, pegylated IL-10, through its potential antifibrotic activity (Mattos et al., 2012), would be helpful in the control of heart fibrosis, along T. cruzi infection, making exogenous IL-10 supplementation an extremely interesting approach to be tested in future studies.

\section{THE INTERLEUKIN 2 AXIS IN IMMUNITY AND AUTOIMMUNITY}

Interleukin-2 (IL-2) was first identified as a growth and differentiation factor produced and utilized by $\mathrm{T}$ cells (Liao et al., 2013). IL-2 is mainly produced by CD4 T cells and, upon activation, the production of IL-2 declines along with the $\mathrm{T}$ cell differentiation process (Sallusto et al., 2004). Therefore, memory
T cells produce less IL- 2 than naïve T cells. IL-2 is also produced to a lesser extent by CD8 and NK T cells, some dendritic and mast cells (Liao et al., 2013) There are two types of receptors for IL-2 (IL-2R), the high and the low affinity receptors (Liao et al., 2013). The low affinity receptor is a molecular complex formed by the association of the beta and the common gamma chains. The IL-2R beta chain (CD122) is expressed on T cells and many other cell lineages (Liao et al., 2013). The high affinity receptor has the addition of the IL-2R alpha chain (CD25) to the low affinity molecular complex (Liao et al., 2013). CD25 is mainly expressed in some activated $\mathrm{T}$ and $\mathrm{B}$ cell subpopulations as well as NK cells (Liao et al., 2013). IL-2 is of crucial importance for the $\mathrm{T}$ cell proliferation and survival during activation and differentiation to short-lived memory cells (Liao et al., 2013), being dispensable after the expression of high levels of the IL-7 receptor or the expression of the IL-15 alpha chain receptor (Liao et al., 2013). Therefore, it seems that IL-7 and/or IL-15 rather than IL-2 are the common gamma chain cytokines that help in the proliferation and maintenance of long-lived memory $\mathrm{T}$ cells (Xu et al., 2014). IL-2 is also a potent cytokine, helping CD8 T cell activation and differentiation to effector cells, participating in the process of NK cell activation and development of their lytic activity (Liao et al., 2013). On the other hand, IL-2 is involved in the regulatory arm of the immune response, by augmenting the proliferation of regulatory Foxp $3^{+} \mathrm{T}$ cells and the reinforcement of the FAS/FAS-L immunoregulatory pathway (Liao et al., 2013; Kosmaczewska, 2014). These two opposing functional activities seem to be related to the amount of the cytokine available in the microenvironment (Kosmaczewska, 2014). Therefore, low amounts of IL-2 would favor the immunoregulatory pathway, whereas high amounts would be required for driving effector immune responses (Kosmaczewska, 2014). The role of IL-2 in the immunoregulatory axis of the immune system is evident in mice and humans where the availability of IL-2 was reduced (Liao et al., 2013; Kosmaczewska, 2014). For instance, IL-2R-beta or IL-2R-alpha chain knockout mice develop autoimmune disease and blocking of IL-2 by in vivo treatment with monoclonal antibody to IL-2 accelerates autoimmunity in mice (Setoguchi et al., 2005). In humans, several polymorphisms in the IL-2 pathway have been linked to type I diabetes and loss of function of Foxp $3^{+}$Treg biological activities. In addition, low levels of circulating IL-2 have been associated with different autoimmune diseases (Yamanouchi et al., 2007). Chagasic patients with cardiomyopathy show decreased production of IL-2 by peripheral blood leucocytes (Briceno and Mosca, 1996). However, serum IL-2 levels have been reported to increase in chagasic patients with cardiomyopathy (Poveda et al., 2014). The reasons for the discrepancy are not clear, but IL-2 may be produced by cells trapped in other tissues and the presence of serum neutralizing factors, such as soluble serum CD25RA or anti-cytokine antibodies generated by a dysregulated immune response may reduce IL-2-bioactivity (Campen et al., 1988; Tsybikov et al., 2015). Soluble serum CD25RA and autoantibodies to many different self-antigens and structures have been described in Chagas disease (Moretti et al., 2002; Vicco et al., 2013). Autoimmune diseases usually proceed with lymphopenia and signs of $\mathrm{T}$ cell 
senescence (Stockinger et al., 2004; Thewissen et al., 2007). These characteristics may reflect a dysfunctional thymus and lower T cell output (Thewissen et al., 2005; Vieira et al., 2008). A similar picture has emerged for Chagas' disease. CD4 and CD8 T cells from chagasic patients carry markers of immunosenescence and present an exhausted functional phenotype with diminished production of IL-2 (Albareda et al., 2009, 2015). Increased levels of immunosenescence correlated with more severe forms of the disease (Cardillo et al., 1993; Albareda et al., 2009, 2015). Recent studies have also shown that the thymus is damaged during T. cruzi infection and therefore, lower numbers of Tregs and conventional thymic $\mathrm{T}$ cell emigrants would reach peripheral organs. This diminishes $\mathrm{T}$ cell renew along the infection similarly to what has been previously described in other classical autoimmune diseases (Gonzalez et al., 2016). Therefore, immunesenescence and autoimmunity would prevail in about $30 \%$ of infected people due to the low numbers and poor regulatory activity of Tregs that lack IL-2 produced by the pool of effector conventional T cells.

\section{TOWARD NOVEL STRATEGIES TO TREAT CHRONIC CHAGAS' DISEASE}

The study of acute and chronic phases of infection with intracellular pathogens, such as T. cruzi, allows the elucidation of the mechanisms and conditions that may be targeted to reprogram the host immune system by using tools that interfere with components of the regulatory arm of the immune system machinery. This knowledge would certainly result in a better understanding of the necessary balance to achieve or reestablish the health of the host during T. cruzi infection, thus providing new strategies to treat Chagas' disease. In this regard, the in vivo biological activity of nondepleting antibodies to CD25 seems to

\section{REFERENCES}

Albareda, M. C., Olivera, G. C., Laucella, S. A., Alvarez, M. G., Fernandez, E. R., Lococo, B., et al. (2009). Chronic human infection with Trypanosoma cruzi drives CD4+ T cells to immune senescence. J. Immunol. 183, 4103-4108. doi: 10.4049/jimmunol.0900852

Albareda, M. C., Perez-Mazliah, D., Natale, M. A., Castro-Eiro, M., Alvarez, M. G., Viotti, R., et al. (2015). Perturbed T cell IL-7 receptor signaling in chronic Chagas disease. J. Immunol. 194, 3883-3889. doi: 10.4049/jimmunol.1402202

Andrade, D. V., Gollob, K. J., and Dutra, W. O. (2014). Acute chagas disease: new global challenges for an old neglected disease. PLoS Negl. Trop. Dis. 8:e3010. doi: 10.1371/journal.pntd.0003010

Bonney, K. M., and Engman, D. M. (2015). Autoimmune pathogenesis of chagas heart disease: looking back, looking ahead. Am. J. Pathol. 185, 1537-1547. doi: 10.1016/j.ajpath.2014.12.023

Briceno, L., and Mosca, W. (1996). Defective production of interleukin 2 in patients with Chagas' disease. Purified IL-2 augments in vitro response in patients with chagasic cardiomyopathy. Mem. Inst. Oswaldo Cruz 91, 601-607.

Bustamante, J. M., Craft, J. M., Crowe, B. D., Ketchie, S. A., and Tarleton, R. L. (2014). New, combined, and reduced dosing treatment protocols cure Trypanosoma cruzi infection in mice. J. Infect. Dis. 209, 150-162. doi: 10.1093/infdis/jit420

Campen, D. H., Horwitz, D. A., Quismorio, F. P. Jr., Ehresmann, G. R., and Martin, W. J. (1988). Serum levels of interleukin-2 receptor and activity of rheumatic reinforce rather than inhibit the function of regulatory $\mathrm{T}$ cells either in mice or humans (Nihei et al., 2014; Huss et al., 2015). In addition, the in vivo administration of IL-2 or complexes of IL-2/anti-IL-2 to increase the numbers and functional activity of regulatory $\mathrm{T}$ cells would also be a valuable approach to be used in Chagas' disease (Letourneau et al., 2010). Low doses of IL-2 have already been used successfully in many clinical trials (Matsuoka et al., 2013; Kosmaczewska, 2014; Humrich et al., 2015). However, a consensus for the low-dose regimen of IL-2 administration has not been established and serious concerns about which dose of IL-2 to use in different clinical conditions remains open to debate (Perol et al., 2014).

The notion concerning the manipulation of Treg cells either by antibodies to CD25, IL-2, and/or IL-10 might open up a new avenue for therapeutic strategies in Chagas' disease. It should be noted that more pre-clinical studies, using different strains of T. cruzi in combination with distinct strains of mice should be performed in order to better establish these conceptual clinical interventions, perhaps in addition to more acquiescent schemes of benznidazole treatment (Bustamante et al., 2014).

\section{AUTHOR CONTRIBUTIONS}

JM Design the paper hypothesis, wrote the first draft. FC Design the paper hypothesis, wrote the first draft. LP Design the paper hypothesis, wrote the first draft.

\section{ACKNOWLEDGMENTS}

We thank Vinicius N. Motta for reviewing the manuscript. This work was supported by PAPES/CNPq/FIOCRUZ and Fundação Octacílio Gualberto, Faculdade de Medicina de Petropolis (FMPFASE). diseases characterized by immune system activation. Arthritis Rheum. 31, 1358-1364. doi: 10.1002/art.1780311103

Cardillo, F., de Pinho, R. T., Antas, P. R., and Mengel, J. (2015). Immunity and immune modulation in Trypanosoma cruzi infection. Pathog. Dis. 73:ftv082. doi: 10.1093/femspd/ftv082

Cardillo, F., Falcao, R. P., Rossi, M. A., and Mengel, J. (1993). An age-related gamma delta $\mathrm{T}$ cell suppressor activity correlates with the outcome of autoimmunity in experimental Trypanosoma cruzi infection. Eur. J. Immunol. 23, 2597-2605.

de Araujo, F. F., Vitelli-Avelar, D. M., Teixeira-Carvalho, A., Antas, P. R., Assis Silva Gomes, J., Sathler-Avelar, R., et al. (2011). Regulatory T cells phenotype in different clinical forms of Chagas' disease. PLoS Negl. Trop. Dis. 5:e992. doi: 10.1371/journal.pntd.0000992

Gonzalez, F. B., Calmon-Hamaty, F., No Seara Cordeiro, S., Fernandez Bussy, R., Spinelli, S. V., D’Attilio, L., et al. (2016). Trypanosoma cruzi experimental infection impacts on the thymic regulatory T cell compartment. PLoS Negl. Trop. Dis. 10:e0004285. doi: 10.1371/journal.pntd.0004285

Humrich, J. Y., von Spee-Mayer, C., Siegert, E., Alexander, T., Hiepe, F., Radbruch, A., et al. (2015). Rapid induction of clinical remission by low-dose interleukin2 in a patient with refractory SLE. Ann. Rheum. Dis. 74, 791-792. doi: 10.1136/annrheumdis-2014-206506

Hunter, C. A., Ellis-Neyes, L. A., Slifer, T., Kanaly, S., Grunig, G., Fort, M., et al. (1997). IL-10 is required to prevent immune hyperactivity during infection with Trypanosoma cruzi. J. Immunol. 158, 3311-3316. 
Huss, D. J., Mehta, D. S., Sharma, A., You, X., Riester, K. A., Sheridan, J. P., et al. (2015). In vivo maintenance of human regulatory T cells during CD25 blockade. J. Immunol. 194, 84-92. doi: 10.4049/jimmunol.1402140

Kosmaczewska, A. (2014). Low-dose interleukin-2 therapy: a driver of an imbalance between immune tolerance and autoimmunity. Int. J. Mol. Sci. 15, 18574-18592. doi: 10.3390/ijms151018574

Laucella, S. A., Riarte, A., Prado, N., Zapata, J., and Segura, E. L. (2001). alpha 4 Integrins and sialyl Lewis $\mathrm{x}$ modulation in chronic Chagas disease: further evidence of persistent immune activation. Scand. J. Immunol. 53, 514-519. doi: 10.1046/j.1365-3083.2001.00916.x

Lee, B. Y., Bacon, K. M., Bottazzi, M. E., and Hotez, P. J. (2013). Global economic burden of Chagas disease: a computational simulation model. Lancet Infect. Dis. 13, 342-348. doi: 10.1016/S1473-3099(13)70002-1

Letourneau, S., van Leeuwen, E. M., Krieg, C., Martin, C., Pantaleo, G., Sprent, J., et al. (2010). IL-2/anti-IL-2 antibody complexes show strong biological activity by avoiding interaction with IL-2 receptor alpha subunit CD25. Proc. Natl. Acad. Sci. U.S.A. 107, 2171-2176. doi: 10.1073/pnas.0909 384107

Liao, W., Lin, J. X., and Leonard, W. J. (2013). Interleukin-2 at the crossroads of effector responses, tolerance, and immunotherapy. Immunity 38, 13-25. doi: 10.1016/j.immuni.2013.01.004

Maguire, J. H. (2015). Treatment of Chagas' disease-time is running out. N. Engl. J. Med. 373, 1369-1370. doi: 10.1056/NEJMe1510170

Matsuoka, K., Koreth, J., Kim, H. T., Bascug, G., McDonough, S., Kawano, Y., et al. (2013). Low-dose interleukin-2 therapy restores regulatory $\mathrm{T}$ cell homeostasis in patients with chronic graft-versus-host disease. Sci. Transl. Med. 5, 179 ra143. doi: 10.1126/scitranslmed.3005265

Mattos, A., de Jager-Krikken, A., de Haan, M., Beljaars, L., and Poelstra, K. (2012). PEGylation of interleukin-10 improves the pharmacokinetic profile and enhances the antifibrotic effectivity in $\mathrm{CCl}(4)$-induced fibrogenesis in mice. J. Control. Release 162, 84-91. doi: 10.1016/j.jconrel.2012. 05.041

Mengel, J. O., and Rossi, M. A. (1992). Chronic chagasic myocarditis pathogenesis: dependence on autoimmune and microvascular factors. Am. Heart J. 124, 1052-1057.

Miyara, M., Chader, D., Sage, E., Sugiyama, D., Nishikawa, H., Bouvry, D., et al. (2015). Sialyl lewis x (CD15s) identifies highly differentiated and most suppressive FOXP3high regulatory T cells in humans. Proc. Natl. Acad. Sci. U.S.A. 112, 7225-7230. doi: 10.1073/pnas.1508224112

Moretti, E., Basso, B., Cervetta, L., Brigada, A., and Barbieri, G. (2002). Patterns of cytokines and soluble cellular receptors in the sera of children with acute chagas' disease. Clin. Diagn. Lab. Immunol. 9, 1324-1327. doi: 10.1128/cdli.9.6.13241327.2002

Morillo, C. A., Marin-Neto, J. A., Avezum, A., Sosa-Estani, S., Rassi, A. Jr., Rosas, F., et al. (2015). Randomized trial of benznidazole for chronic Chagas' cardiomyopathy. N. Engl. J. Med. 373, 1295-1306. doi: 10.1056/NEJMoa1507574

Nihei, J., Cardillo, F., Dos Santos, W. L., Pontes-de-Carvalho, L., and Mengel, J. (2014). Administration of a nondepleting anti-CD25 monoclonal antibody reduces disease severity in mice infected with Trypanosoma cruzi. Eur. J. Microbiol. Immunol. (Bp). 4, 128-137. doi: 10.1556/EuJMI.4.2014.2.6

Oft, M. (2014). IL-10: master switch from tumor-promoting inflammation to antitumor immunity. Cancer Immunol Res 2, 194-199. doi: 10.1158/23266066.CIR-13-0214

Perol, L., Martin, G. H., Maury, S., Cohen, J. L., and Piaggio, E. (2014). Potential limitations of IL-2 administration for the treatment of experimental acute graft-versus-host disease. Immunol. Lett. 162, 173-184. doi: 10.1016/j.imlet.2014.10.027
Poveda, C., Fresno, M., Girones, N., Martins-Filho, O. A., Ramirez, J. D., Santi-Rocca, J., et al. (2014). Cytokine profiling in Chagas disease: towards understanding the association with infecting Trypanosoma cruzi discrete typing units (a BENEFIT TRIAL sub-study). PLOS ONE 9:e91154. doi: 10.1371/journal.pone.0091154

Rassi, A. Jr., Rassi, A., and Marin-Neto, J. A. (2010). Chagas disease. Lancet 375, 1388-1402. doi: 10.1016/S0140-6736(10)60061-X

Roffe, E., Rothfuchs, A. G., Santiago, H. C., Marino, A. P., Ribeiro-Gomes, F. L., Eckhaus, M., et al. (2012). IL-10 limits parasite burden and protects against fatal myocarditis in a mouse model of Trypanosoma cruzi infection. J. Immunol. 188, 649-660. doi: 10.4049/jimmunol.1003845

Sallusto, F., Geginat, J., and Lanzavecchia, A. (2004). Central memory and effector memory T cell subsets: function, generation, and maintenance. Annu. Rev. Immunol. 22, 745-763. doi: 10.1146/annurev.immunol.22.012703.104702

Setoguchi, R., Hori, S., Takahashi, T., and Sakaguchi, S. (2005). Homeostatic maintenance of natural Foxp3(+) CD25(+) CD4 $(+)$ regulatory $\mathrm{T}$ cells by interleukin (IL)-2 and induction of autoimmune disease by IL-2 neutralization. J. Exp. Med. 201, 723-735. doi: 10.1084/jem.20041982

Stockinger, B., Kassiotis, G., and Bourgeois, C. (2004). Homeostasis and T cell regulation. Curr. Opin. Immunol. 16, 775-779. doi: 10.1016/j.coi.2004.09.003

Thewissen, M., Linsen, L., Somers, V., Geusens, P., Raus, J., and Stinissen, P. (2005). Premature immunosenescence in rheumatoid arthritis and multiple sclerosis patients. Ann. N.Y. Acad. Sci. 1051, 255-262. doi: 10.1196/annals.1361.066

Thewissen, M., Somers, V., Venken, K., Linsen, L., van Paassen, P., Geusens, P., et al. (2007). Analyses of immunosenescent markers in patients with autoimmune disease. Clin. Immunol. 123, 209-218. doi: 10.1016/j.clim.2007.01.005

Tsybikov, N. N., Egorova, E. V., Kuznik, B. I., Fefelova, E. V., and Magen, E. (2015). Anticytokine autoantibodies in chronic rhinosinusitis. Allergy Asthma Proc. 36, 473-480. doi: 10.2500/aap.2015.36.3880

Umezawa, E. S., Stolf, A. M., Corbett, C. E., and Shikanai-Yasuda, M. A. (2001). Chagas' disease. Lancet 357, 797-799. doi: 10.1016/S0140-6736(00)04174-X

Vicco, M. H., Ferini, F., Rodeles, L., Cardona, P., Bontempi, I., Lioi, S., et al. (2013). Assessment of cross-reactive host-pathogen antibodies in patients with different stages of chronic Chagas disease. Rev. Esp. Cardiol. (Engl. Ed). 66, 791-796. doi: 10.1016/j.rec.2013.05.028

Vieira, Q. F., Kayser, C., Kallas, E. G., and Andrade, L. E. (2008). Decreased recent thymus emigrant number is associated with disease activity in systemic lupus erythematosus. J. Rheumatol. 35, 1762-1767.

Xu, Y., Zhang, M., Ramos, C. A., Durett, A., Liu, E., Dakhova, O., et al. (2014). Closely related T-memory stem cells correlate with in vivo expansion of CAR.CD19-T cells and are preserved by IL-7 and IL-15. Blood 123, 3750-3759. doi: 10.1182/blood-2014-01-552174

Yamanouchi, J., Rainbow, D., Serra, P., Howlett, S., Hunter, K., Garner, V. E., et al. (2007). Interleukin-2 gene variation impairs regulatory $\mathrm{T}$ cell function and causes autoimmunity. Nat. Genet. 39, 329-337. doi: 10.1038/ng1958

Conflict of Interest Statement: The authors declare that the research was conducted in the absence of any commercial or financial relationships that could be construed as a potential conflict of interest.

Copyright (c) 2016 Mengel, Cardillo and Pontes-de-Carvalho. This is an open-access article distributed under the terms of the Creative Commons Attribution License (CC $B Y)$. The use, distribution or reproduction in other forums is permitted, provided the original author(s) or licensor are credited and that the original publication in this journal is cited, in accordance with accepted academic practice. No use, distribution or reproduction is permitted which does not comply with these terms. 